\title{
Volcanic Ash at Kuk
}

\author{
Russell Blong, Thomas Wagner and Jack Golson
}

\section{Introduction}

Layers of volcanic ash, or tephra, to use a more technical term, are deposited in an instant of geological time. As most thin $(<100 \mathrm{~mm})$ ash layers are probably deposited in around 24 hours, this is pretty close to an instant of human time as well. In an environment such as Kuk Swamp where there is little else to provide absolute (or sometimes even relative) time markers, accurate identification of tephra remnants is of fundamental significance to interpretation of features resulting from both human activities and biophysical processes. Without the numerous layers of volcanic ash at Kuk, it would be much harder to interpret the history of swamp agriculture.

The rapid deposition of ash in a very short period of time means that if we can determine the age of an ash remnant at one site with reasonable certainty and then positively correlate that remnant with other remnants of the same ash, we have established a chronostratigraphic marker-a time horizon that can have value far beyond the confines of the Kuk archaeological site.

This chapter discusses the nature of thin falls of volcanic ash and the ages of the ash deposits at Kuk. It then explores a really big question-where did these tephras come from? Which volcanoes in PNG produced such large eruptions?

\section{Volcanic ash or tephra}

Almost all eruptions produce tephra. This is erupted from the vent, forming a rising column with rock, gas and water. As the hot mass rises, it mixes in the surrounding air and continues to rise-sometimes, in a big eruption, reaching 20 to $30 \mathrm{~km}$ above the earth's surface. Most of the ash is composed of new volcanic material, fragmented by explosions and vesiculated (punched full of small holes) by expanding gases. The frothy new magma fragments are chilled rapidly by contact with the atmosphere, taking on a glassy appearance (Fig. 7.1), but some of the new magma cools more slowly so that it is crystalline rather than glassy.

Most ash lands within a few kilometres of the vent and contributes to the typically conical shape of volcanoes (see Mt Ambra in Fig. 7.2). The usual pattern of ash deposition is elliptical around the vent, with the long axis of the ellipse indicating the dominant wind direction. At distances of more than a few tens of kilometres from the vent, ash falls more gradually through the atmosphere, with larger and denser particles deposited earlier and closer to the vent. Winds in the boundary layer (just above the ground surface) may sweep ash into eddies and against topographic and other obstacles. As fine ash particles form ideal surfaces for the condensation of water vapour, rainfall during ashfall is not uncommon. Rain may also flush the ash from the atmosphere, increasing deposition here and reducing deposition there. 


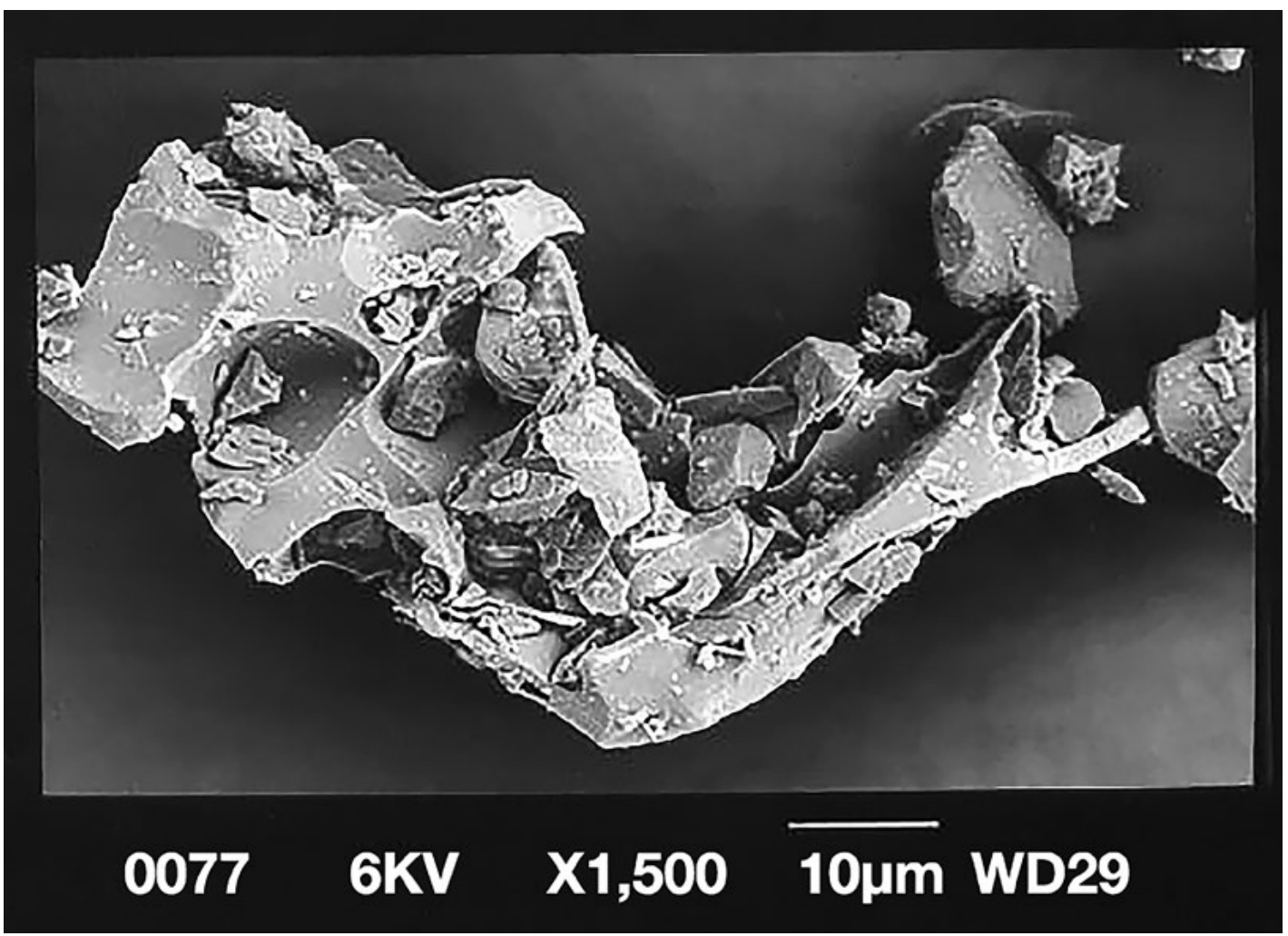

Figure 7.1 Vesicular glass shard from the eruption of Vulcan, Rabaul, 19 September 1994. The shard is less than $0.1 \mathrm{~mm}$ in length, about the same as the median size of those from Tibito Tephra at Kuk. Source: Photograph by Linda Coates.

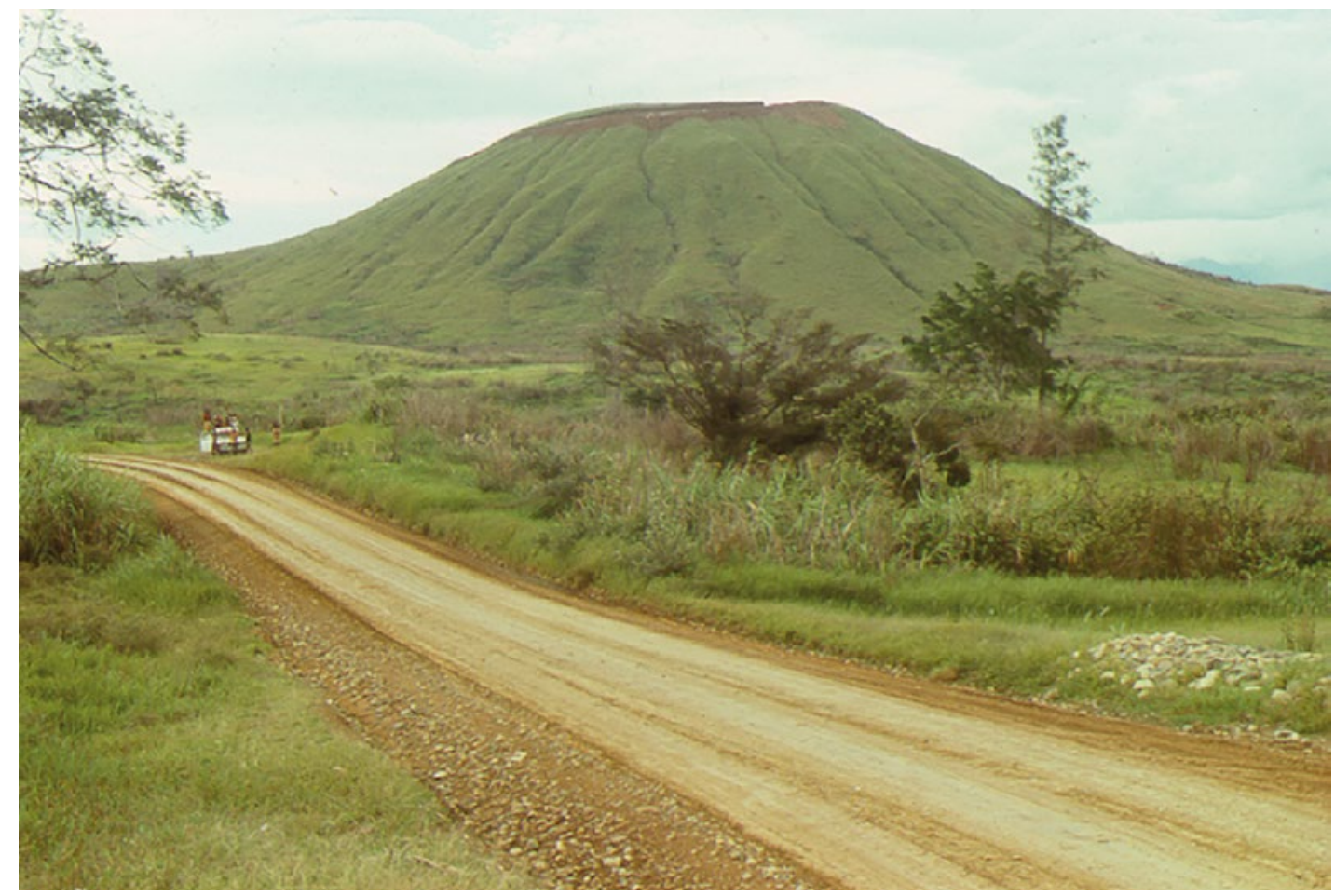

Figure 7.2 The small, beautifully preserved Mt Ambra, $3 \mathrm{~km}$ west of the Kuk site, view to north. Source: Photograph by Russell Blong, 1971. 
In most parts of PNG, volcanic ash falls from the atmosphere onto a vegetated ground surface. Acid aerosols attached to the ash may make the particles sticky so that they cling to the vegetation in one area, while tropical downpours may wash much of the ash through the vegetation onto the ground surface in another. Ash that arrives fluffy and loose like fresh snow quickly compacts under the impact of raindrops. Some ash is eroded and deposited elsewhere.

Chemical processes alter the ash almost as soon as it has been deposited. Potassium, sulphur and other plant nutrients are released and vegetation such as grasses and crops quickly sprout. The glassy components of the ash break down and form new minerals such as clays. This process is enhanced by mechanical and biological activities. In tropical environments with intense rainfalls and very high rates of biological activity, a 1-2 mm deposit of light-coloured ash, readily identifiable immediately after deposition, can become all but invisible within a matter of weeks. Such deposits are preserved only in environments where the rate of biological turnover is exceptionally low-for example, on high (cold) mountains and on the bottoms of lakes. Ash deposits a few centimetres thick will survive much longer but are gradually reworked and destroyed as an identifiable layer by the growth and decay of plants, the burrowing activities of soil organisms, the rooting of pigs and the gardening activities of humans. As time passes, fewer and fewer remnants of the ash layer remain, with identifiable deposits restricted to short lenses of reworked ash sandwiched between older and younger deposits with different characteristics and different origins.

\section{Field investigations of volcanic ash at Kuk}

Thin layers of volcanic ash were identified at Kuk on our first visit in 1970, when the Research Station was at an early stage of development and there were long stratigraphic exposures in the walls of newly dug drains. Subsequently, we found reference to the occurrence of thin tephras in cores taken for pollen analysis from swamps near Wabag (Flenley 1967) and Mt Hagen (Powell 1970a) in the middle and later 1960s respectively, under the auspice of a project on the vegetation history of the New Guinea highlands directed by Donald Walker of ANU. Thus Flenley (1967: 229, 273) refers to thin bands of 'silt' in his cores, samples of which were subsequently identified as volcanic ash under laboratory examination (cf. Powell 1970a: Tables 9.1-9.5).

Over the next seven years at Kuk, extended efforts were made to determine the characteristics and chronology of the volcanic ash record. As deeper sections of the swamp were drained and the exposure of new drain walls stretched to tens of kilometres, new ash layers were identified, characterised, placed in stratigraphic position and, where possible, dated by radiocarbon analyses of associated deposits.

Correlation of the thin tephras was no simple matter. Rarely were there remnant layers more than 1-2 m long exposed in the walls of drains or excavation trenches and only occasionally were more than three or four tephras revealed in a single exposure. Nonetheless, it is now believed that there are at least 20 separate tephra layers preserved at the Kuk site. Table 7.1 summarises present knowledge of tephras at Kuk in stratigraphic order and in terms of their field characteristics, including colour, texture and consistency. Occasionally, other properties like the appearance of samples under low magnification, mineralogy and magnetic susceptibility signatures have been used to assist identification. The descriptions reflect grain sizes, admixture of adjacent organic materials, reworking characteristics, pedological alteration and the degree of weathering. Rarely is one characteristic sufficient to uniquely identify a tephra remnant. 
The most distinctive and best known tephras at Kuk are Tibito, Olgaboli, Kim and Ep. The first three named occur relatively high in the sequence and have distinctive appearances and stratigraphic positions. Ep Tephra is the thickest tephra layer in the swamp. Below Ep Tephra the various ash layers are poorly known. They are similar in appearance with few distinguishing characteristics and, as they are deep in the swamp, there are few exposures. The tephras below Ep are not considered much further in this discussion because they are very much older than those associated with the archaeological evidence for use of the swamp dating from the last 10,000 years (Table 7.2) and which are the focus of this chapter.

Higher in the sequence, it is often difficult to make a certain identification of individual tephra remnants because many of their physical characteristics are similar. This is the case, for example, with Kenta and Kuning tephras in many exposures, where firm identification as one or the other is only possible when a remnant of Olgaboli Tephra is also present. There is also the question of Komun tephra, characterised by red-and-white speckled clay root-fillings and small pellets. It is possible that at the time when Komun was deposited, Kuk Swamp was a poor site for tephra preservation. However, it is also possible, following the analyses of Tim Denham (2003: Appendix E4.8, Appendix E5), that the soil layer called Komun in Table 7.1 is not a tephra at all since the characteristics of the clay mineralogy are different from those of all other presumed tephras, except Kuning (Sandy 2). Denham (pers. comm., 2004) is also inclined to doubt that Kuning is a tephra. So even above Ep Tephra we are unsure of the exact number of eruptions that have deposited volcanic ash at Kuk. If Komun and Kuning are not tephras, however, we have no clear idea what they might be.

Table 7.1 lists a range of names for tephras at Kuk, incidentally giving a potted history of our understanding of the tephra sequence. As we became more confident of our identifications of the tephra remnants and their associated characteristics, we used approved stratigraphic procedure, with each tephra being assigned a local name. For example, Tibito was named after the small Tibito Creek that flows through Kuk Swamp. Tibito Creek was also the first site where this tephra was identified. The names we applied to two of the thin tephras at Kuk, Tibito and Olgaboli, are on the Australian Stratigraphic Units Database as members of a list of names that have formally been reserved for use with PNG tephras (Colin Pain, Geoscience Australia, pers. comm., 2009). This means that the formal names are Tibito Tephra and Olgaboli Tephra, with Tephra having an uppercase $\mathrm{T}$ (see www.ga.gov.au/data-pubs/data-standards/reference-databases/stratigraphicunits). The same applies to Tomba Tephra and Bune Tephra, which are mentioned later.

Table 7.2 sets out best estimates of the ages of the thin tephras identified at Kuk. In some cases, multiple age estimates are available. With one exception, Tibito b), in the decade of the $\mathrm{AD}$ 1660s, all age estimates in the table are based on radiocarbon dates on associated organic material calibrated to calendar years BP. The tephrochronological record at Kuk has been developed through intensive investigation of many kilometres of exposure. The record is not perfect and is still subject to reinterpretation, but it is certainly one of the finest records of thin tephras available anywhere in the world. Although there are questions about the number and character of tephras preserved in deeper parts of Kuk Swamp, we can be confident that at least 10 thin tephras have been deposited since Ep Tephra fell between about 18,500 and 14,500 years ago. Tibito and Olgaboli Tephras have been identified in the field over wide areas since 1970 (Blong 1982; cf. Haberle 1998a: Appendix 1). This, with support from geochemical fingerprinting, makes it possible to draw isolines of distribution and thickness. Figure 7.3 does this for Tibito Tephra. 


\begin{tabular}{|c|c|c|c|c|c|c|c|c|}
\hline 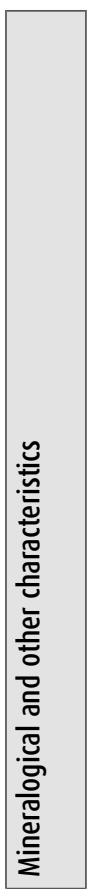 & 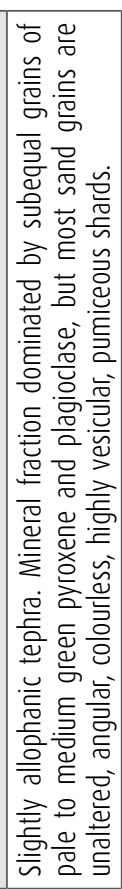 & 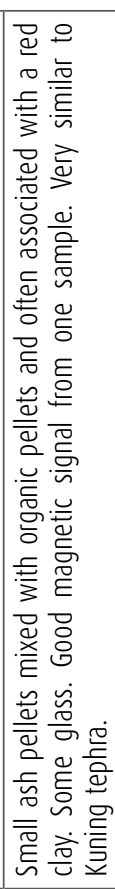 & 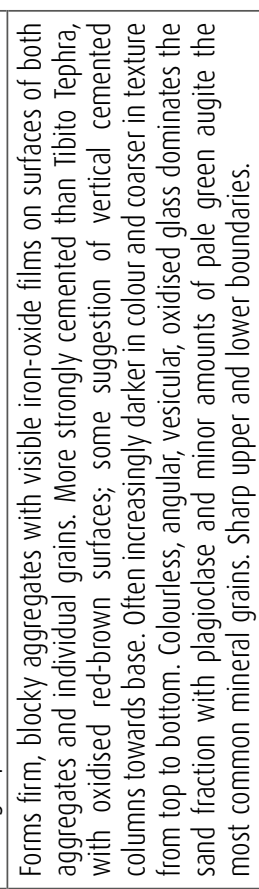 & 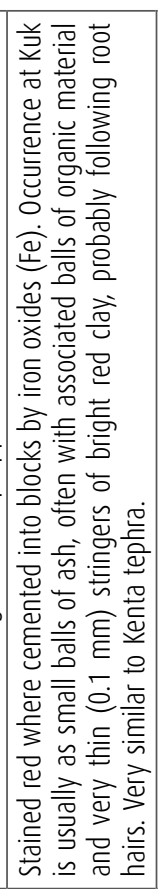 & 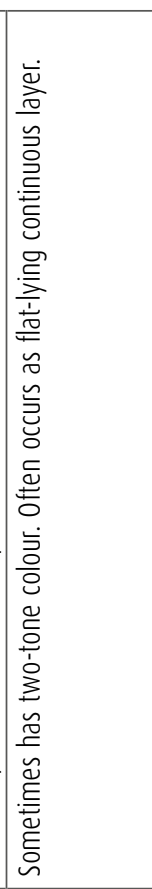 & 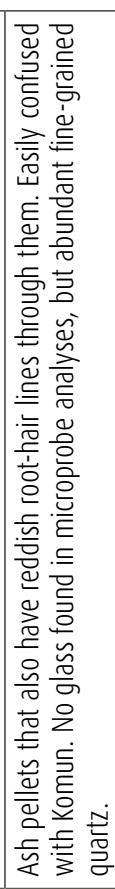 & 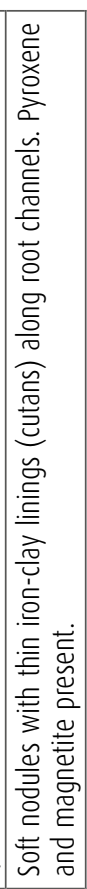 & 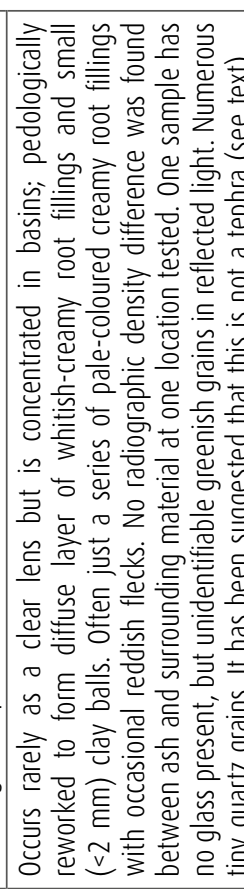 \\
\hline 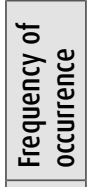 & 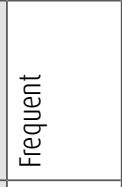 & 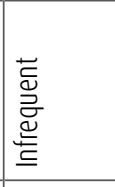 & 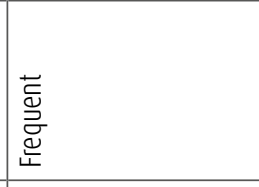 & 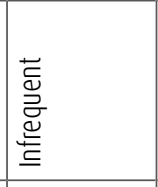 & 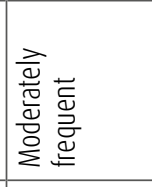 & 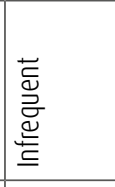 & 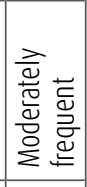 & 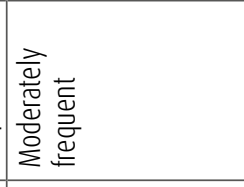 \\
\hline 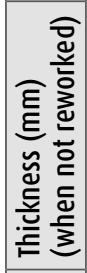 & 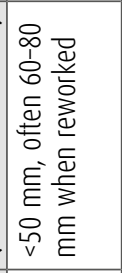 & 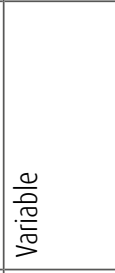 & 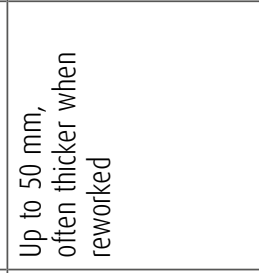 & $\frac{0}{\frac{0}{0}}$ & $\begin{array}{l}\underset{E}{E} \\
\stackrel{\text { V }}{\overparen{V}} \\
\end{array}$ & 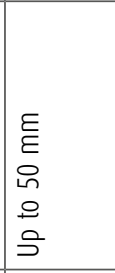 & 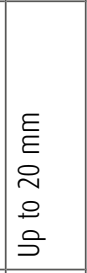 & 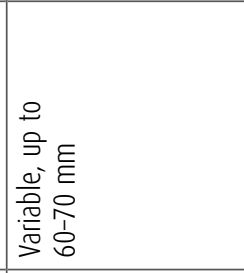 \\
\hline 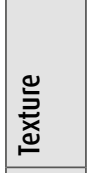 & 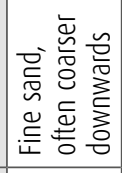 & 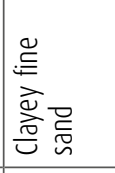 & 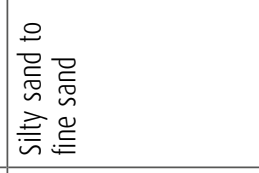 & 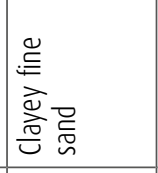 & 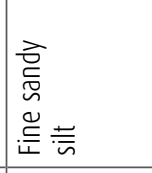 & 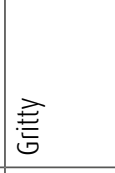 & 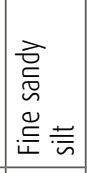 & 党 \\
\hline 흥 & 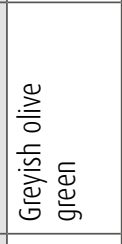 & 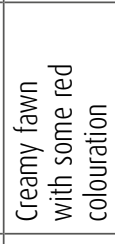 & 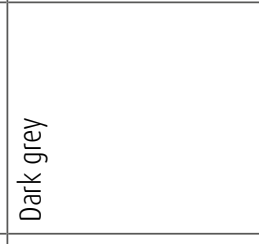 & 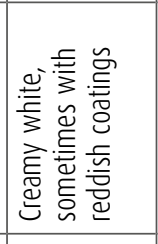 & 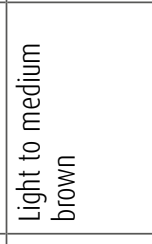 & 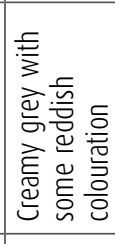 & 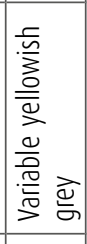 & 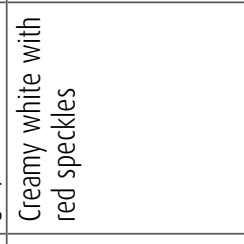 \\
\hline 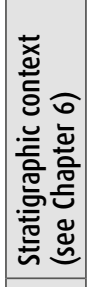 & $\begin{array}{l}\overline{\bar{n}} \\
\bar{q} \\
\overline{0} \\
\overline{0}\end{array}$ & $\begin{array}{l}\overline{\overline{0}} \\
\overline{\tilde{q}} \\
\overline{0} \\
\overline{0} \\
\end{array}$ & $\begin{array}{l}\overline{\bar{n}} \\
\bar{q} \\
\overline{\ddot{d}} \\
\bar{b} \\
\end{array}$ & 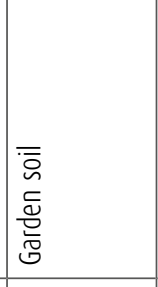 & 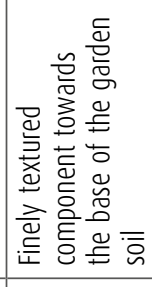 & 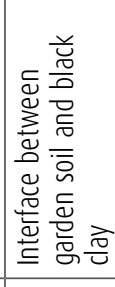 & \begin{tabular}{|l}
$\frac{\lambda}{0}$ \\
$\frac{\overrightarrow{0}}{0}$ \\
$\frac{0}{0}$ \\
\end{tabular} & 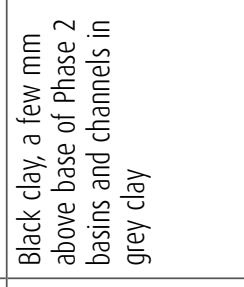 \\
\hline 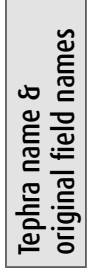 & 总 & 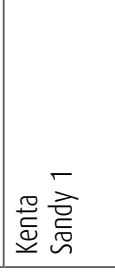 & \begin{tabular}{|l}
$\overline{\overline{0}}$ \\
$\overline{\overline{0}}$ \\
$\overline{0} 0$
\end{tabular} & 镸衮 & 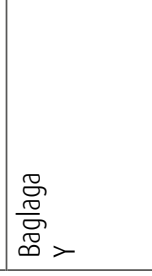 & 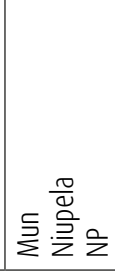 & $\frac{E}{\frac{E}{2}} \propto$ & 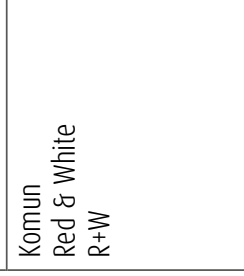 \\
\hline
\end{tabular}




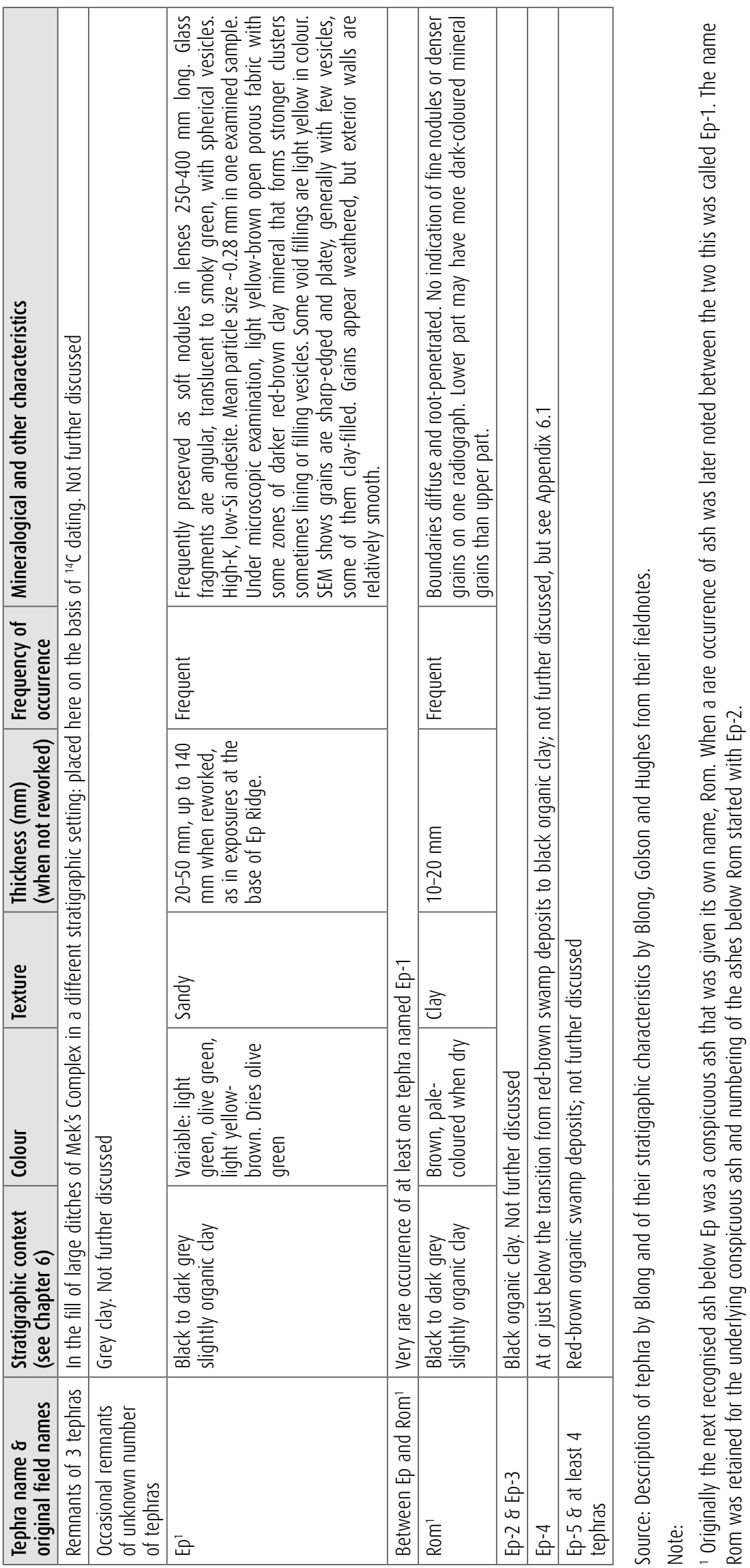


Table 7.2 Chronology of tephras at Kuk.

\begin{tabular}{|c|c|c|}
\hline Tephra & $\begin{array}{l}\text { Date of ashfall (in cal. yr BP, where BP = } \\
\text { Before Present and Present = AD 1950) }\end{array}$ & Source \\
\hline \multirow[t]{2}{*}{ Tibito } & $\begin{array}{l}\text { a) Between 169-154 BP }(35 \%)^{2} \\
\text { Between 304-282 BP }(65 \%)^{2}\end{array}$ & a) Chapter 8 here, pooled mean of five radiocarbon dates \\
\hline & b) In the decade of AD $1660 \mathrm{~s}$ & b) Chapter 8 here \\
\hline \multirow[t]{3}{*}{ Kenta } & Between 930-310 BP3 & Radiocarbon dates: \\
\hline & a) Between 680-310 BP & ANU-3909, $520 \pm 120$, on peat immediately above the ash \\
\hline & b) Between 930-690 BP & $\begin{array}{l}\text { ANU-3823, 890 } \pm 70 \text {, on carbonised wood some } 300 \mathrm{~mm} \\
\text { below the ash } \\
\text { Gillieson et al. 1989: Fig. 6.3, at Yeni Swamp, Jimi Valley }\end{array}$ \\
\hline \multirow[t]{5}{*}{ Olgaboli } & $\begin{array}{l}\text { Between 1190-970 BP }(97 \%)^{2} \\
\text { Between 1230-1210 BP }(3 \%)^{2}\end{array}$ & $\begin{array}{l}\text { Pooled mean of three radiocarbon dates, Haberle 1998a: } 13 \\
\text { and Appendix } 2\end{array}$ \\
\hline & Between 1330-800 BP & Radiocarbon dates: \\
\hline & a) Between 960-800 BP & a) 0ZF140, $1040 \pm 40$, above the ash \\
\hline & b) Between 1330-1180 BP & $\begin{array}{l}\text { b) 0ZF141, } 1400 \pm 40 \text {, above the ash } \\
\text { Sniderman et al. 2009: Table 2, at Mt Ambra crater } 3 \mathrm{~km} \\
\text { from Kuk }\end{array}$ \\
\hline & Between 1280-940 BP & $\begin{array}{l}\text { Coulter et al. 2009: Table 1, using the radiocarbon data } \\
\text { of Sniderman et al. } 2009\end{array}$ \\
\hline \multirow[t]{4}{*}{ Kuning } & Between 1690-930 BP & Radiocarbon dates: \\
\hline & a) Between 1120-930 BP & a) $0 Z F-142,1150 \pm 40$, above the ash \\
\hline & b) Between 1690-1420 BP & $\begin{array}{l}\text { b) } 0 \text { ZF- } 143,1710 \pm 40 \text {, below the ash } \\
\text { Sniderman et al. 2009: Table 2, at Mt Ambra crater } 3 \mathrm{~km} \\
\text { from Kuk }\end{array}$ \\
\hline & Between 1560-1040 BP & $\begin{array}{l}\text { Coulter et al. 2009: Table 1, using radiocarbon data of } \\
\text { Sniderman et al. } 2009\end{array}$ \\
\hline \multirow[t]{5}{*}{ Baglaga } & Between 2650-1950 BP & $\begin{array}{l}\text { Denham et al. 2003: Table S2, Y ash: Table S1 for } \\
\text { contributing dates }\end{array}$ \\
\hline & Between 2700-1820 BP & Radiocarbon dates: \\
\hline & a) Between 2110-1820 BP & a) OSF-144, 2030 \pm 50 , above the ash \\
\hline & b) Between 2700-2340 BP & $\begin{array}{l}\text { b) } 0 Z F-145,2450 \pm 40 \text {, below the ash } \\
\text { Sniderman et al. 2009: Table } 2 \text {, from the crater of Mt Ambra } \\
3 \mathrm{~km} \text { from Kuk }\end{array}$ \\
\hline & Between 2400-1980 BP & $\begin{array}{l}\text { Coulter et al. 2009: Table 1, using radiocarbon data of } \\
\text { Sniderman et al. } 2009\end{array}$ \\
\hline Mun & Between 2730-2120 BP & $\begin{array}{l}\text { Chapter } 6 \text { here, note E following Fig. 6.10, citing Denham } \\
\text { et al. } 2003\end{array}$ \\
\hline \multirow[t]{5}{*}{ Kim } & Between 3980-3630 BP & $\begin{array}{l}\text { Denham et al. 2003: Table S2, R ash: Table S1 for } \\
\text { contributing dates }\end{array}$ \\
\hline & Between 4140-3690 BP & Radiocarbon dates: \\
\hline & a) Between 4140-3730 BP & a) $0 Z F-146,3680 \pm 50$, above the ash \\
\hline & b) Between 3980-3690 BP & $\begin{array}{l}\text { b) } 0 Z F-147,3610 \pm 50 \text {, below the ash } \\
\text { Sniderman et al. 2009: Table } 2 \text {, from the crater of Mt Ambra } \\
3 \text { km from Kuk }\end{array}$ \\
\hline & Between 3970-3870 BP & $\begin{array}{l}\text { Coulter et al. 2009: Table 1, using radiocarbon data } \\
\text { of Sniderman et al. } 2009\end{array}$ \\
\hline Komun & Between 6440-5990 BP & $\begin{array}{l}\text { Denham et al. 2003: Table S2, R+W ash: Table S1 for } \\
\text { contributing dates }\end{array}$ \\
\hline
\end{tabular}




\begin{tabular}{|c|c|c|}
\hline Tephra & $\begin{array}{l}\text { Date of ashfall (in cal. yr BP, where BP = } \\
\text { Before Present and Present = AD 1950) }\end{array}$ & Source \\
\hline \multirow{3}{*}{$\begin{array}{l}\text { Remnants of } \\
\text { three tephras in } \\
\text { ditches of Mek's } \\
\text { Complex }\end{array}$} & Between 7430-5990 BP & Radiocarbon dates: \\
\hline & a) Between 6440-5990 BP & $\begin{array}{l}\text { a) the limiting dates of Komun (see above), which is later } \\
\text { than Mek's }\end{array}$ \\
\hline & b) Between 7430-6640 BP3 & $\begin{array}{l}\text { b) radiocarbon date ANU-1704, } 6150 \pm 180 \text {, on cellulose from } \\
\text { wood at the base of a ditch at the complex }\end{array}$ \\
\hline \multirow{3}{*}{$\begin{array}{l}\text { Rare remnants } \\
\text { of unknown } \\
\text { number of ashes } \\
\text { in grey clay }\end{array}$} & Between 10,230-6440 BP & Radiocarbon dates for grey clay: \\
\hline & a) Between 7420-6440 BP & $\begin{array}{l}\text { a) end of grey clay deposition, Chapter } 6 \text { here, note D } \\
\text { following Fig. } 6.10 \text {, citing Denham et al. } 2003\end{array}$ \\
\hline & b) Between 10,230-9780 BP & $\begin{array}{l}\text { b) start of grey clay deposition, Chapter } 6 \text { here, note C } \\
\text { following Fig. 6.10, citing Denham et al. } 2003\end{array}$ \\
\hline \multirow[t]{3}{*}{ Ep } & Between 18,480-14,920 BP ${ }^{4}$ & Radiocarbon dates: \\
\hline & a) Between 16,400-14,920 BP & $\begin{array}{l}\text { a) ANU-1461D, } 12,890 \pm 140, \mathrm{NaOH} \text {-insoluble fraction of clay } \\
\text { sample from immediately above the ash at Kuk }\end{array}$ \\
\hline & b) Between 18,480-17,010 BP & $\begin{array}{l}\text { b) ANU-3215, } 14,510 \pm 230, \text { on lake mud } 80 \mathrm{~mm} \text { below the } \\
\text { ash at a small pond near Mt Ambra } 3 \mathrm{~km} \text { from Kuk }\end{array}$ \\
\hline \multicolumn{3}{|l|}{ Ep-11 } \\
\hline \multirow[t]{3}{*}{ Rom } & Between $24,500-18,900 \mathrm{BP}^{4}$ & Radiocarbon dates: \\
\hline & a) Between 20,030-18,900 BP & $\begin{array}{l}\text { a) ANU-1460, } 16,320 \pm 220 \text {, on clayey peat 0-50 mm above } \\
\text { the ash }\end{array}$ \\
\hline & b) Between 24,500-23,380 BP & $\begin{array}{l}\text { b) ANU-3186, 20,070 } 230 \text {, on wood from } 150 \mathrm{~mm} \text { diameter } \\
\text { log } 30 \mathrm{~mm} \text { below the base of the ash }\end{array}$ \\
\hline \multicolumn{3}{|l|}{ Ep-2 and -3} \\
\hline $\begin{array}{l}\text { Ep-4 at the } \\
\text { organic/inorganic } \\
\text { transition }\end{array}$ & Minimum age between $40,660-31,200 \mathrm{BP}^{4}$ & $\begin{array}{l}\text { Range of five dates from four samples from the base of black } \\
\text { organic clay at drains A9E and A10f/g; see Appendix } 6.1\end{array}$ \\
\hline Ep-5 to -8 & & \\
\hline
\end{tabular}

Source: Where not specified in the table, from data collated by Golson from his fieldnotes and ANU Radiocarbon Laboratory report sheets.

Notes:

1 See note 1 of Table 7.1 .

2 Percentage (\%) probability of the true age falling within the calibrated age range; all the ranges indicated by notes 3 and 4 are 100\%, except for one in the final entry, Ep minus 4.

${ }^{3}$ Calibrations by Simon Haberle using Calib 6.0.0 (Stuiver and Reimer 1993); a calibration for ANU-1704 is published here for the first time.

${ }^{4}$ Calibrations by Simon Haberle using IntCal09 (Reimer et al. 2009) of radiocarbon dates published here for the first time.

The detailed investigation of the volcanic ash layers at Kuk summarised in Table 7.1 has spawned two related studies. The rest of this chapter is the subject of one: the question of which volcanoes were the sources for the tephras preserved at Kuk. Chapter 8 deals with the second study, the relationship between Tibito Tephra and widespread stories of a Time of Darkness (taim tudak), and its date. 


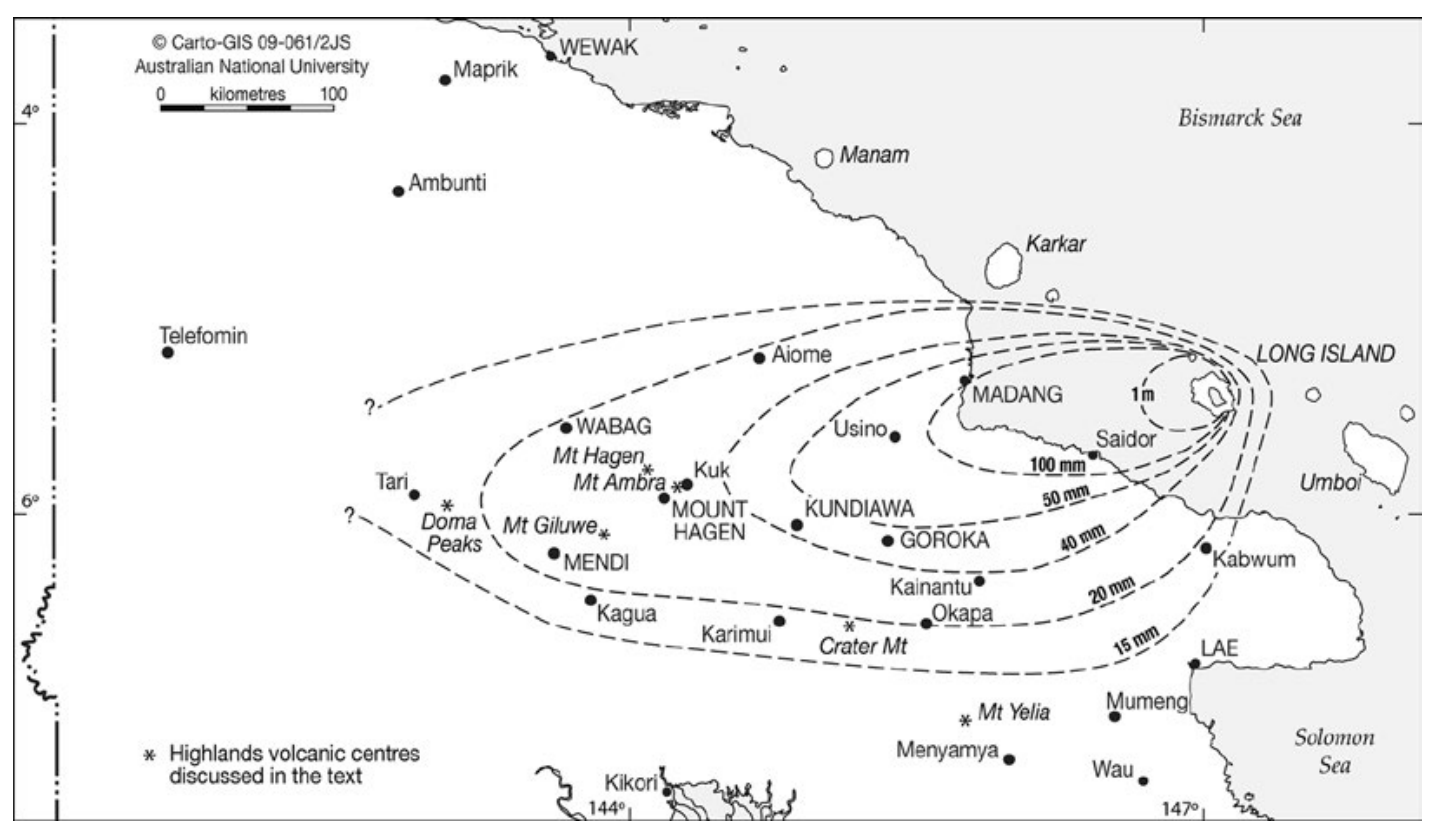

Figure 7.3 Distribution of Tibito Tephra based on extensive fieldwork.

Source: Drawing by Jennifer Sheehan, CartogIS Services, College of Asia and the Pacific, ANU, based on Blong (1982: Fig. 29), reproduced with permission.

\section{Sources of the thin tephras found at Kuk}

So where did the Kuk tephras come from? This is an important question because these volcanoes might still be active today. With dozens of volcanoes in the New Guinea region (Fig. 7.4) to choose from, we needed a variety of methods to narrow down the selection, including fieldwork and chemical analysis.

As a start, New Guinea volcanoes can be divided into groups based on their geologic setting, as follows: volcanoes of the highlands, the area within which the Kuk site is situated (Fig. 7.3); the Bismarck volcanic arc, a long chain of volcanoes off New Guinea's northern coast (Fig. 7.4); and more distant sources such as the volcanoes of eastern Papua, the Admiralty Islands, the Tabar-Feni arc and Bougainville (Fig. 7.4). Some of these areas can be eliminated from further consideration based on the eruptive history of the volcanoes and the physical characteristics of the tephra layers.

Another consideration is that as a tephra deposit becomes progressively thinner with distance from its point of origin (see Fig. 7.3), we should be able to trace it back to the source volcano. Extensive fieldwork, however, shows that the tephras do not thicken toward any of the volcanoes near Kuk. This evidence is consistent with other indications that highlands volcanoes ceased erupting tens of thousands of years before the Kuk tephras were deposited. For example, Mt Ambra (Fig. 7.2), located just $3 \mathrm{~km}$ away (Fig. 7.3), has the Kuk tephras in its summit crater, meaning the tephras are younger than Mt Ambra's last eruption. The larger nearby volcanoes such as Mt Hagen and Mt Giluwe (Fig. 7.3) are also too old to have produced the Kuk tephras. The last major eruption of Mt Hagen produced Tomba Tephra at the same time as Mt Giluwe produced Bune Tephra. The massive Tomba Tephra mantles all of the major eruptive centres in the western highlands, including Mt Ambra and at least some of the apparently youthful cones south of Mt Giluwe. These deposits are certainly older than 50,000 years (Pain and Blong 1976). 


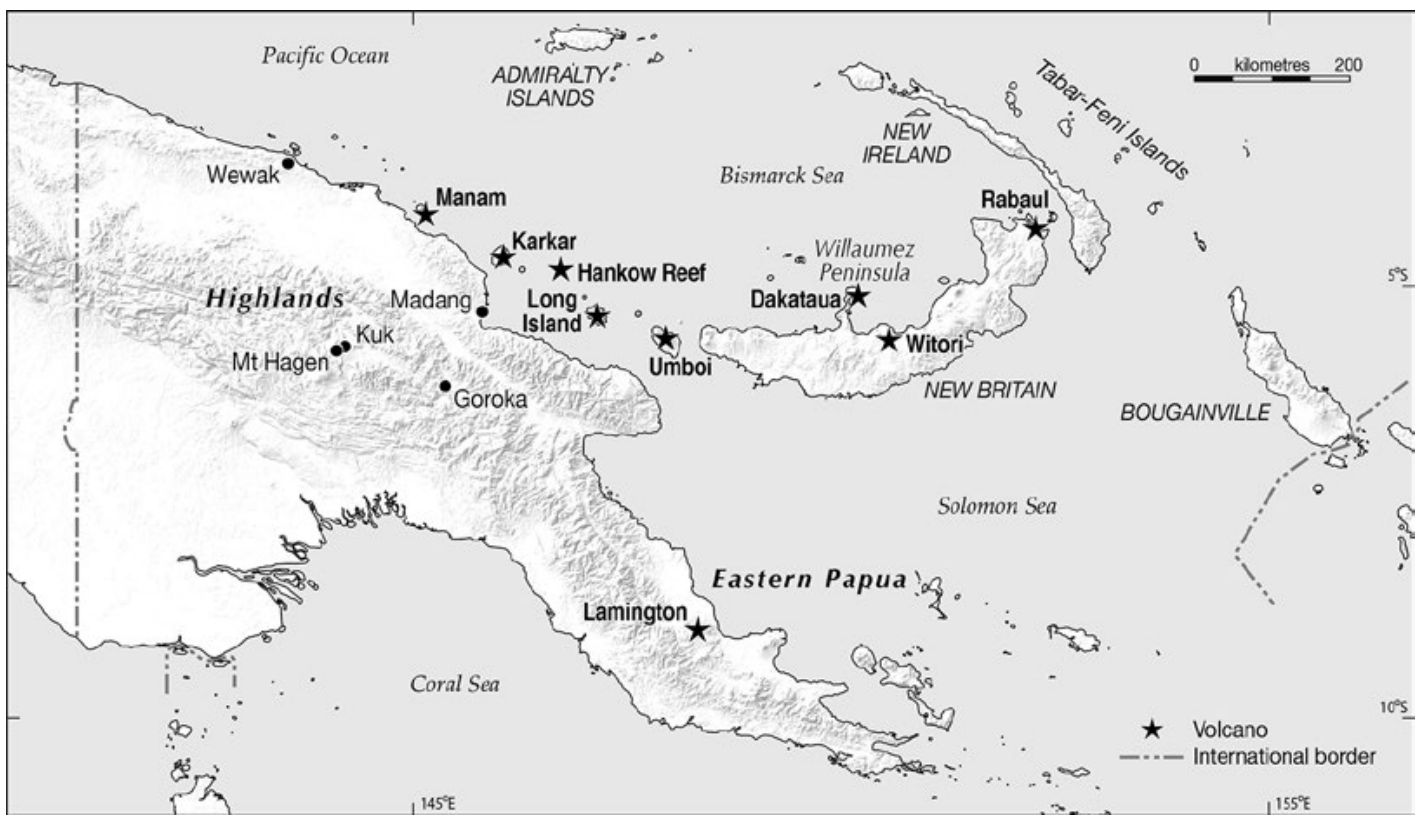

Figure 7.4 Map of volcanic areas in PNG. The Bismarck volcanic arc comprises the eruptive centres along the north coast from Wewak to Rabaul.

Source: Jennifer Sheehan, CartogIS Services, College of Asia and the Pacific, ANU.

Highlands volcanoes located further away from Kuk are also unlikely sources. Doma Peaks, near Tari in Southern Highlands Province (Fig. 7.3), is often cited as the youngest possibly still active volcanic centre in the highlands. Though it has fumaroles - hot gases seeping from the groundin the crater and other sites nearby (Taylor 1971), the deposits from its last eruption are covered by those of Tomba Tephra from Mt Hagen (Colin Pain, pers. comm., 2007). Southeast of Kuk, the major highlands volcanoes are Crater Mountain and Mt Yelia, about $100 \mathrm{~km}$ and $200 \mathrm{~km}$ distant, respectively (Fig. 7.3). Little is known about the eruptive history of Crater Mountain, but the last significant eruption of Mt Yelia occurred after 17,500 years BP (SUA-835) but substantially earlier than 5000 years BP (SUA-836) (Blong, fieldnotes, 1977). Nevertheless, none of the Kuk tephras thicken towards the east-southeast. This observation also eliminates Mt Lamington and the eastern Papua volcanoes from consideration as sources for the Kuk tephras (Fig. 7.4).

Since the tephrostratigraphic information suggests that none of the thin tephras found at Kuk after the fall of Ep, between about 18,500 and 14,500 years ago, erupted from volcanic centres on the New Guinea mainland, it is necessary to look elsewhere. The next nearest group of volcanoes is formed by those of the Bismarck arc.

\section{Possible Bismarck arc sources}

The Bismarck arc is a $1000 \mathrm{~km}$ long string of volcanoes that stretches along the north coast of PNG from near Wewak in the west to Rabaul at the eastern end of the island of New Britain (Fig. 7.4). The arc contains over 30 volcanic centres, many of which have been active in historical times. An ash cloud of sufficient size to deposit tephra at Kuk would require a very large eruption of a Bismarck arc volcano, one that would probably collapse a significant portion of the volcano's edifice. We briefly consider the known eruptions of large magnitude along the Bismarck arc over the last 20,000 years. Kuk lies generally west or southwest of all of them. We recognise that this discussion is likely to be incomplete as the eruptive histories of some volcanoes are poorly known. 
The volcanoes nearest Kuk are Karkar Island and Long Island, $230 \mathrm{~km}$ and $320 \mathrm{~km}$ away respectively. Both volcanoes have central collapse features (calderas) and stratigraphic records of large explosive eruptions during the period under review—-three at Karkar and three at Long (Pain, Blong and McKee 1981; Pain and McKee 1981). Local legends (Mennis 1981) suggest that another volcano, active in the last few thousand years but now submerged, lies between these two. Called Yomba, the volcano's peak could have been destroyed during a large eruption, leaving just a submarine reef. Although Mennis (1981) proposed Hankow Reef as the site of ancestral Yomba, recent underwater mapping shows topographic features that imply the last eruption at Hankow Reef is substantially older than the Yomba legend (Silver et al. 2009).

Witori and Dakataua, respectively $710 \mathrm{~km}$ and $670 \mathrm{~km}$ from Kuk, are volcanoes on Willaumez Peninsula on the island of New Britain that have produced major eruptions. Five such eruptions occurred at Witori in the last 6000 years, one at Dakataua (Machida et al. 1996; Petrie and Torrence 2008; McKee, Neall and Torrence 2011). At the eastern end of New Britain, Rabaul caldera, $930 \mathrm{~km}$ from Kuk, also has a record of massive eruptions (Nairn et al. 1996), the major ones being two within the last 10,000 years and another three in the previous 10,000 years. Hargy volcano, also on the north coast of New Britain, had two major eruptions between about 14,000 and 11,000 years ago (McKee, Neall and Torrence 2011).

All of the caldera-forming eruptions under discussion injected vast amounts of tephra into the upper atmosphere and the generally southwest-flowing upper airstream could have deposited it at Kuk. However, Rabaul, Hargy, Witori and Dakataua are so far away $(930 \mathrm{~km}, 800 \mathrm{~km}$, $710 \mathrm{~km}$ and $670 \mathrm{~km}$ respectively) that truly enormous eruptions would have been required to deposit tephra at these distances from the source volcano. Consequently, Karkar and Long Island seem the most likely sources for the tephras at Kuk. However, our understanding of the eruptive histories of these volcanoes is imperfect. The uncertainties and overlaps in the dates for tephra deposition at Kuk and the cataclysmic eruptions of these volcanoes are too large to allow precise correlations. So we have tried something else-chemical fingerprinting. Just as people have individual fingerprints, volcanoes have fingerprints in terms of the chemical composition of the magmas that they produce. By analysing the tephras we can compare them against a database compiled by Dr Wally Johnson (accessed 1998), the foremost authority on PNG volcanism, of chemical analyses of tephras and lavas from potential source volcanoes.

\section{Geochemical characterisation of the Kuk tephras}

Characterising the Kuk tephras geochemically is not straightforward. Lying in a swamp for hundreds to thousands of years, the tephras react with groundwater in a way that alters their chemical composition. On the positive side, this alteration produces the fertile soils of the highlands (see Chapter 8, section 'Soil replenishment') by changing volcanic glass to clay and releasing key plant nutrients like potassium and sodium. However, for fingerprinting, we need a technique that looks beyond the alteration process. Using an electron microscope, we can image and analyse the tephras on a very fine scale, down to millionths of a metre (see Fig. 7.1). This allows us to preferentially select and analyse pristine shards of volcanic glass. Figure 7.5 displays the most important results of this work. The fields represent many analyses of the glass shards from 16 samples of Tibito Tephra and 13 samples of Olgaboli Tephra.

The data in Figure 7.5 show that Olgaboli Tephra represents a simple eruption of basaltic-andesite of almost uniform composition. Tibito Tephra, on the other hand, contains a wider range of magma types, highly variable by volcanic standards, extending from basalt to dacite and forming a much broader field on this graph. The other major tephras found at Kuk, Kim and Ep, are not shown in Figure 7.5, but are similar in composition to Tibito Tephra. 
The remaining Kuk tephras have compositions similar to either Tibito or Olgaboli Tephras (Fig. 7.5), but some display the intriguing characteristic of being split between the two groups. Based on a variety of evidence, these split tephras may be physical mixtures of two or more tephras at the Kuk site. These and other major findings are summarised in Table 7.3. However, we emphasise that these conclusions are tentative because in several cases only single samples (but multiple grains) have been analysed. A great deal of further work is required before we are able to provide unique matches between the tephras at Kuk and specific deposits on the source volcanoes.

The compositional variation shown in Figure 7.5 also tells us some interesting things about the volcanic sources. The wide range in composition displayed by Tibito Tephra was probably produced by cooling and partial solidification of magmas in the volcano prior to eruption. This variability implies tapping of a complicated volcanic system with diverse pockets of magma in various stages of solidification. The eruption was probably very large and collapsed major portions of the volcano. Because they are similar in composition to Tibito Tephra, two earlier tephras, Kim and Ep, which erupted between about 4000 and 3500 years ago in the first case and about 18,500 and 14,500 in the second (Table 7.2), were almost certainly produced by the same source as Tibito. This would mean that the same behaviour was repeated on timescales exceeding a few thousand years.

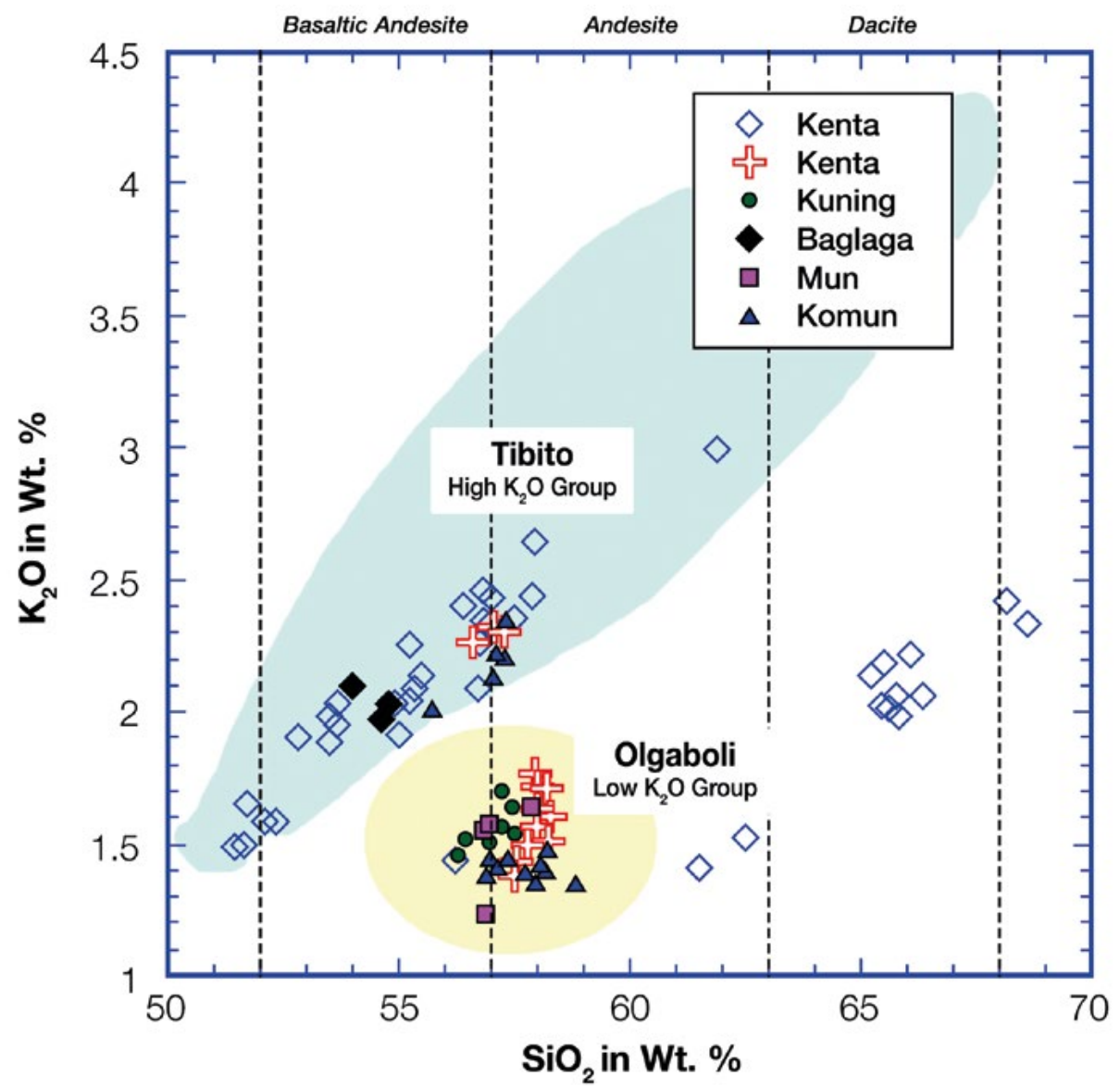

Figure 7.5 Analysis of shards of volcanic glass for tephras at Kuk. Blue field represents analyses of over 80 individual glass shards from Tibito Tephra.

Yellow field represents analyses of over 40 individual glass shards from Olgaboli Tephra. Other tephras are noted in the legend; each data point represents a single glass shard.

Source: Drawing by Tom Wagner. 
Table 7.3 Compositional characteristics of tephras at Kuk.

\begin{tabular}{|c|c|c|}
\hline Tephra name & Characteristics & Volcanic source \\
\hline Tibito & $\begin{array}{l}\text { Highly variable composition-basalt to dacite-but generally forming trends } \\
\text { consistent with magmatic differentiation processes }\end{array}$ & Long Island \\
\hline Kenta & $\begin{array}{l}\text { Probably represents a mixture of Tibito- and Olgaboli-like tephras. Two samples } \\
\text { analysed, one of which also displays a unique low- } k_{2} 0 \text { trend not observed in } \\
\text { other samples, but which appears consistent with magmatic differentiation }\end{array}$ & Long Island or Karkar \\
\hline Olgaboli & Basaltic-andesite of restricted composition, with lower $\mathrm{K}_{2} 0$ contents than Tibito & Karkar \\
\hline Kuning & One sample analysed, similar to Olgaboli, low $\mathrm{K}_{2} 0$ group & Karkar \\
\hline Baglaga & One sample analysed, basaltic-andesite that falls on Tibito trend & Long Island \\
\hline Mun & One sample analysed, similar to Olgaboli, low $\mathrm{K}_{2} 0$ group & Karkar \\
\hline Kim & Five samples analysed, all on Tibito trend, limited to basalt-andesite and andesite & Long Island \\
\hline Komun & $\begin{array}{l}\text { Two samples analysed and probably represent a mixture of Tibito- and Olgaboli- } \\
\text { like tephras. They display some anomalous compositions in other elements. } \\
\text { If Komun is a tephra, these samples may have been affected by alteration }\end{array}$ & Long Island \\
\hline Ep & $\begin{array}{l}\text { Five samples analysed, most on Tibito trend, limited to basaltic-andesite to andesite, } \\
\text { but some have very high } \mathrm{K}_{2} \mathrm{O} \text { contents off the trend. These may be alteration } \\
\text { effects; there is very little fresh glass and it is difficult to find unaltered fragments }\end{array}$ & Long Island \\
\hline
\end{tabular}

Source: Samples of tephra collected by Blong and analysed by Blong and Wagner.

By comparison, as already noted, the volcanic system that produced Olgaboli Tephra was simpler. With little variation in composition, the eruption tapped a single magma body or at least a generally less differentiated system overall. In addition, this system also repeats its behaviour, but on shorter timescales of less than a thousand years, as evidenced by the similarity between Olgaboli and two of the minor tephras, Kuning and Mun, which erupted respectively between around 1700 and 900 years ago and 2750 and 2100 years (Table 7.2). In addition, these tephras are not as thick as those in the Tibito group, which implies production by smaller or more distant eruptions, or that the wind directions were different.

\section{Identifying the volcanic sources}

To identify the source volcanoes for the Kuk tephras, we compared them to chemical analyses of tephras and lavas with known sources. We focused primarily on the large eruptions from Bismarck arc volcanoes as only large eruptions are likely to have deposited tephra as far away as Kuk. Nonetheless, we also searched Wally Johnson's database of New Guinea volcanics (accessed 1998). The results indicate that all of the recent tephras found at Kuk were probably erupted from volcanoes in the Bismarck arc.

Figure 7.6 compares the Kuk tephras with samples collected from the Bismarck arc volcanoes by grouping individual chemical components into mineral units to facilitate interpretation, using the method of Grove (1993). The Kuk tephras form fields in the centre of the diagram. The major Rabaul eruptions all plot near the bottom of the diagram, far from the majority of the Kuk tephras. Other Rabaul data are scattered across the diagram, and while there is some overlap of these with the group at the bottom of the diagram, there are only a few glass shards from Kuk tephras in this area. As in the case of Rabaul, major Witori and Dakataua eruptions form fields in the bottom left of the diagram, away from the Kuk tephras, though some analyses of samples from these volcanoes are more scattered. 


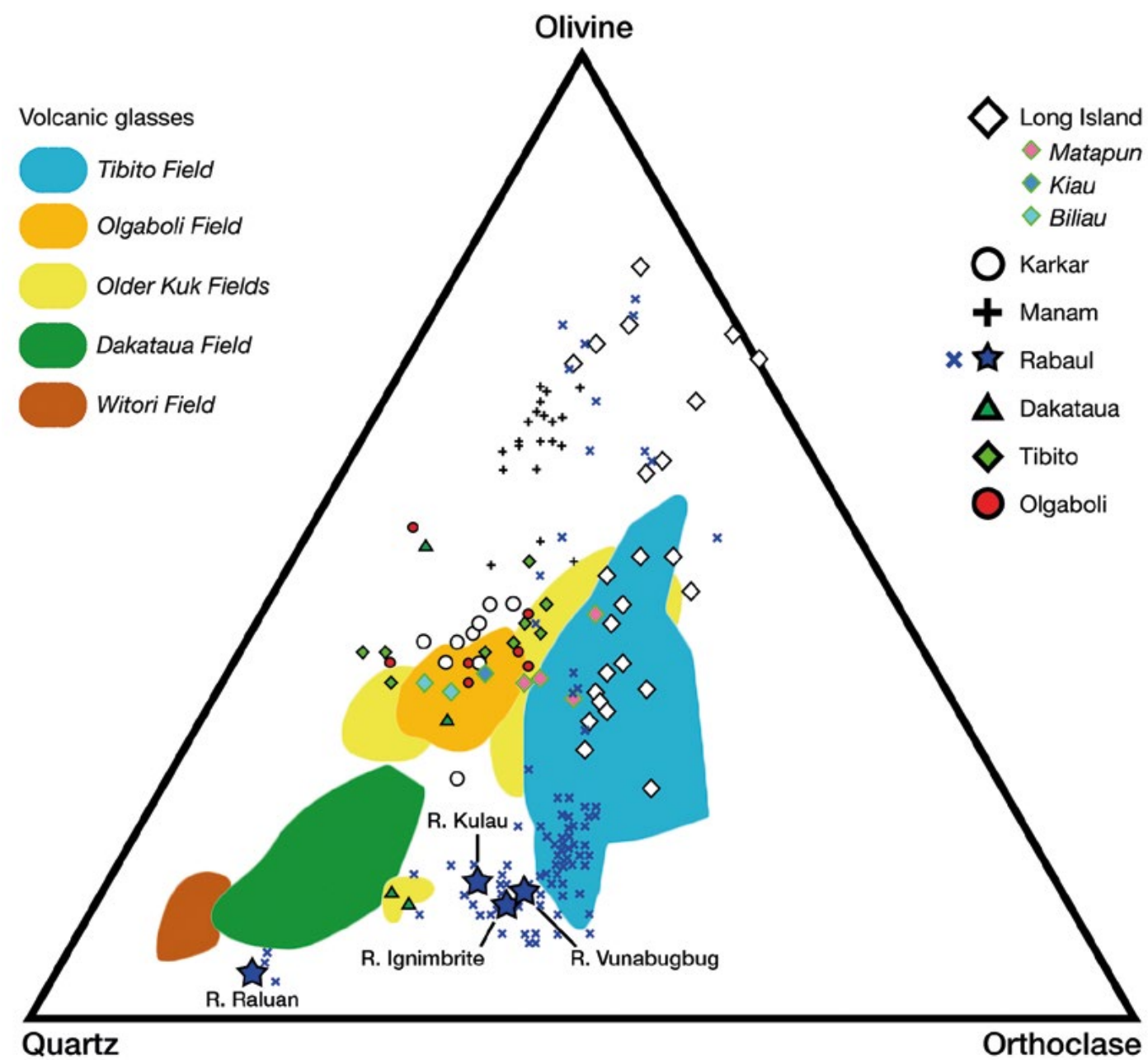

Figure 7.6 Mineralogical composition of some Kuk tephras and various Bismarck arc volcanic samples. Volcanic glasses from the Kuk tephras are shown by the blue (Tibito), orange (olgaboli) and yellow (others) fields. The volcanic glasses in the Kuk tephras were analysed as individual glass fragments by Electron Microprobe. Systematic differences are to be expected. Data points show volcanic rocks from New Britain, Karkar, Long Island and Manam volcanoes; different symbols for the one volcanic source refer to different beds. Generally, the volcanic samples are from whole rocks analysed by X-Ray Fluorescence (XRF). Samples from only four of five major explosive Witori eruptions have been analysed here. Similarly, samples from only four of the five such eruptions of Rabaul volcano have been analysed. Dakataua and Witori fields are based on unpublished data provided by Robin Torrence, reproduced with permission.

Source: Drawing by Tom Wagner.

The overall point to take away from Figure 7.6 is that the Bismarck arc volcanoes that are located very far from Kuk—Rabaul, Witori and Dakataua (Fig. 7.4)—show significant compositional differences from the Kuk tephras and are unlikely to be their source. This is despite there having been very large eruptions from these volcanoes in the last 15,000 years or so (Machida et al. 1996; Nairn et al. 1996; McKee, Neall and Torrence 2011).

The western half of the Bismarck arc hosts a number of potential sources (Fig. 7.4). The Kuk tephras are most similar to eruptive products from Long Island and Karkar volcanoes in terms of both major elements and the critical minor elements $\mathrm{K}_{2} \mathrm{O}$ (potassium oxide) and $\mathrm{TiO}_{2}$ (titanium oxide). The Kuk tephra samples are also similar to some samples from Umboi, Langila and Cape Gloucester (on and near the western end of New Britain, see Fig. 7.4), though there are relatively few analyses available for these volcanoes and no evidence that they have experienced cataclysmic caldera-forming eruptions. Table 7.3 lists the likely source or sources for each Kuk tephra. 


\section{Conclusions}

Numerous thin tephra units have been identified at Kuk and at a number of other sites across the highlands, providing unique chronostratigraphic markers that are absolutely essential to understanding the history of the Kuk site. Extensive fieldwork has eliminated the possibility that any highlands volcanoes were the sources of these tephras. Based on stratigraphic work around several volcanoes along the Bismarck arc, the ages of major eruptions there (Pain, Blong and McKee 1981; Pain and McKee 1981; Polach 1981) and analyses of wind speeds and directions (Blong 1981), it is clear that Karkar and Long Islands are the most likely sources for all the tephras found at Kuk younger than and including Ep (Table 7.2).

Compelling arguments also come from the compositional characteristics of eruptives from Karkar and Long Island volcanoes, which match the geochemical properties of the Kuk tephras. Figure 7.6 shows that many Long Island samples overlap with the Kuk tephras, including both the Tibito and Olgaboli groups. It also shows that the Karkar samples have less overall compositional variation than the Long Island samples. These characteristics are consistent with Karkar being the source for the Olgaboli group and Long Island for the Tibito group and some other tephras. However, there is still much research to do, particularly on the source volcanoes and on tephras identified at a range of sites across the highlands, before we can uniquely correlate each of the Kuk tephras to a well-dated eruption.

\section{Acknowledgements}

Major contributions were made to the tephrostratigraphy at Kuk over a period of years by Wal Ambrose, Philip Hughes, the late Ron Lampert, Frank Oldfield, Colin Pain, Jocelyn Powell, Marjorie Sullivan and various more temporary members of the Kuk team. We thank particularly Philip Hughes and Colin Pain for their major contributions to Tables 7.1 and 7.2. We also thank Wally Johnson and Robin Torrence for access to unpublished data on New Guinea volcanics. 
This text is taken from Ten Thousand Years of Cultivation at Kuk Swamp in the Highlands of Papua New Guinea, edited by Jack Golson, Tim Denham, Philip Hughes, Pamela Swadling and John Muke, published 2017 by ANU Press, The Australian National University, Canberra, Australia. 